\title{
The Daily Cloud-to-Ground Lightning Flash Density in the Contiguous United States and Finland
}

\author{
ANTTI MÄKELÄ AND PEKKA Rossi \\ Finnish Meteorological Institute, Helsinki, Finland \\ DAVID M. SCHULTZ \\ Division of Atmospheric Sciences, Department of Physics, University of Helsinki, and Finnish Meteorological Institute, \\ Helsinki, Finland, and Centre for Atmospheric Science, School of Earth, Atmospheric and Environmental Sciences, \\ University of Manchester, Manchester, United Kingdom
}

(Manuscript received 26 May 2010, in final form 23 November 2010)

\begin{abstract}
A method is developed to quantify thunderstorm intensity according to cloud-to-ground lightning flashes (hereafter ground flashes) determined by a lightning-location sensor network. The method is based on the ground flash density $N_{D}$ per thunderstorm day (ground flashes per square kilometer per thunderstorm day) calculated on $20 \mathrm{~km} \times 20 \mathrm{~km}$ fixed squares. Because the square size roughly corresponds to the area covered by a typical thunderstorm, the flash density for one square defines a unit thunderstorm for the purposes of this study. This method is tested with ground flash data obtained from two nationwide lightning-location systems: the National Lightning Detection Network (NLDN) in the contiguous United States and the portion of the Nordic Lightning Information System (NORDLIS) in Finland. The distribution of daily ground flash density $N_{D}$ is computed for all of Finland and four $800000 \mathrm{~km}^{2}$ regions in the United States (identified as western, central, eastern, and Florida). Although Finland and all four U.S. regions have median values of $N_{D}$ of $0.01-$ 0.03 flashes per square kilometer per thunderstorm day-indicating that most thunderstorms produce relatively few ground flashes regardless of geographical region-the most intense $1 \%$ of the storms (as measured by the 99th percentiles of the $N_{D}$ distributions within each region) show much larger differences among regions. For example, the most intense $1 \%$ of the $N_{D}$ distributions is 1.3 flashes per square kilometer per thunderstorm day in the central U.S. region, but only 0.2 flashes per square kilometer per thunderstorm day in Finland. The spatial distribution of the most intense $1 \%$ of the $N_{D}$ distributions illustrates that the most intense thunderstorm days occur in the central United States and upper Midwest, which differs from the maxima of the average annual flash density $N_{A}$ and the number of thunderstorm days $T_{D}$, both of which occur in Florida and along the coast of the Gulf of Mexico. This method for using $N_{D}$ to quantify thunderstorm intensity is applicable to any region as long as the detection efficiency of the lightning-location network is high enough or known. This method can also be employed in operational forecasting to provide a quantitative measure of the lightning intensity of thunderstorms relative to climatology.
\end{abstract}

\section{Introduction}

The intensity of a thunderstorm can be expressed in several ways. For example, in the United States, a severe thunderstorm is defined as a storm producing lightning/ thunder and large hail $[1$ in. $(2.5 \mathrm{~cm})$ and larger (changed from $3 / 4$ in. as of January 2010; G. Carbin 2010, personal communication)], strong wind gusts $\left[50 \mathrm{kt}\left(26 \mathrm{~m} \mathrm{~s}^{-1}\right)\right.$

Corresponding author address: Antti Mäkelä, Finnish Meteorological Institute, P.O. Box 503, FIN-00101, Helsinki, Finland. E-mail: antti.makela@fmi.fi and greater], and/or a tornado (e.g., Galway 1989). Thunderstorm intensity might also be expressed by the incurred damages, although the damage depends on where the storm occurred and the full extent of the damage may not always be known or represented with the available reports (e.g., Speheger et al. 2002; Trapp et al. 2006; Doswell et al. 2009). Another measure is the kinematic intensity, an index measuring storm intensity derived from the peak vertical velocity, updraft volume, and vertical airmass flux in the mixed-phase region (Lang and Rutledge 2002). Unfortunately, computing this index requires specialized measurements from multiple 
instrumentation, so it is not practical over most geographical areas. Another way to express the intensity of a thunderstorm is by some measure of a thunderstormrelated phenomenon (e.g., precipitation and lightning). For example, lightning-location data from surface-based or satellite-based sensors can be used to derive a direct measure of the production rate of lightning in the thunderstorm and consequently its intensity. Specifically, Zipser et al. (2006) discussed several measures of the intensity of convective storms as measured remotely from satellite, and Boccippio et al. (2001) show flash rates in the United States measured both with satellite and ground-based systems.

Two measures that can be derived from the lightninglocation data are the cloud-to-ground flash rate and cloud-to-ground flash density (hereafter ground flash rate and ground flash density). These quantities have been used widely since the introduction of modern lightninglocation systems (e.g., Peckham et al. 1984; Orville 1991; Orville and Silver 1997; Huffines and Orville 1999; Orville and Huffines 2001; Zajac and Rutledge 2001). Ground flash rate is expressed as the number of flashes per unit time per unit area, and ground flash density is the ground flash rate integrated over time, expressed as the number of flashes per unit area (usually per square kilometer). In the same way that instantaneous precipitation rate from radar data or rain gauge data can be used as a measure of the intensity of precipitation, the ground flash rate from a lightning detection network can be used as a measure of the intensity of a thunderstorm. Similarly, the total precipitation over the course of a day or a year is the total depth of water that fell, analogous to the ground flash density, which is an integrated quantity describing the average intensity of a thunderstorm or thunderstorms over a particular region. Ground flash density was first obtained from flash-counter networks (e.g., Prentice 1972) and later obtained from lightninglocation systems (e.g., Orville et al. 1983, 2002; Pinto et al. 2003; Schulz et al. 2005; Soriano et al. 2005; Orville 2008; Antonescu and Burcea 2010). Nevertheless, these lightninglocation systems are not perfect because of their imperfect detection efficiency (e.g., Biagi et al. 2007) and the potential for the misclassification of cloud flashes (e.g., Cummins et al. 1998; Cummins and Murphy 2009).

For long-term statistics in climatological studies, the annual ground flash density $N_{A}$ has been in wide use for decades. With lightning-location systems, a common time scale and grid size for many studies typically has been adopted. A spatial scale has been adopted of about $0.2^{\circ}$ latitude $\times 0.2^{\circ}$ longitude, which at low or midlatitudes corresponds roughly to grid cells roughly $20 \mathrm{~km}$ on a side or an area of $400 \mathrm{~km}^{2}$. This grid size corresponds approximately to the human observing area for visual observations of lightning and thunder (e.g., Fleagle 1949) and to the area of a typical thunderstorm (e.g., Byers and Braham 1949). Using these standard values, the annual ground flash density $N_{A}$ can be compared for many regions around the world, ranging from high values of ground flash density in central Africa, Florida, and Brazil exceeding 10 flashes per square kilometer per year (e.g., Hodanish et al. 1997; Pinto et al. 1999, 2003; Zajac and Rutledge 2001; Christian et al. 2003; Rudlosky and Fuelberg 2010), to values in the Spanish Basque Country of 4-5 flashes per square kilometer per year (Areitio et al. 2001), to regions in Finland and Romania having maximum values of about 2-3 flashes per square kilometer per year in years with strong thunderstorms (Tuomi and Mäkelä 2008; Antonescu and Burcea 2010).

Although these studies using the annual ground flash density $N_{A}$ provide information on the intensity of all thunderstorms combined, they do not provide information about the intensity of individual thunderstorms. For example, a climate with a short thunderstorm season lasting a few months, but with a relatively few intense storms, may yield similar values of $N_{A}$ to a climate with weak or moderate storms uniformly throughout the year.

Despite the value in maps of annual ground flash density, we wish to devise a measure of intensity for individual thunderstorms using ground flash density. To do this, we reconsider the space and time scales involved. We choose the same area as above $\left(400 \mathrm{~km}^{2}\right)$, for reasons discussed previously. For the time scale, we choose one day for two reasons. First, the traditional thunderstorm day, $T_{D}$, (e.g., as measured by human observers) is defined as a $24-\mathrm{h}$ period, so comparisons between these two different measures is natural. Second, although individual convective cells last less than an hour and organized mesoscale convective systems (MCSs) can last many hours, often only one thunderstorm event takes place at a given point within a 24-h period. In situations when more than one thunderstorm event occurs within the grid cell, they may, for statistical purposes, be treated as one thunderstorm. When this happens, the reduced number of storms can be offset by higher flash density per storm.

The purpose of this paper is to show the utility of lightning-location data to quantify the intensity of a thunderstorm using the daily ground flash density $N_{D}$ and to compare this measure to the annual ground flash density $N_{A}$ and the number of thunderstorm days $T_{D}$. In this way, we can map the geographical distribution of thunderstorm intensity. We show results for two very different climatologies: Finland and the United States. We choose Finland because we have easy access to the data and thunderstorm climatologies from high latitudes are not often published. We compare our results to the well-known lightning climatology of the United States to 
illustrate the versatility of our approach and to relate our results to previously published work. Section 2 of this paper describes the data and methods, and section 3 compares and contrasts the annual ground flash density, the number of thunderstorm days, and the daily ground flash density. The calculations in this paper are also compared to previously published research. Section 4 discusses possible applications of ground flash density to researchers and forecasters, and section 5 concludes this paper.

\section{Data and methods}

We first present the mathematical functions used for the analysis of the lightning data. Let $n_{D}$ be the number of ground flashes per day in a $20 \mathrm{~km} \times 20 \mathrm{~km}$ square, and $N_{D}$ be the ground flash density of that square (i.e., $n_{D}$ divided by $400 \mathrm{~km}^{2}$ ). In addition, let $i=1,2,3, \ldots$, $365 y$ be the index of a particular day during the study period of $y$ years. Therefore, $n_{\mathrm{Di}}$ describes the number of ground flashes in a square on the $i$ th day. In each square, the distribution of ground flashes per day can be represented with the set $F\left(n_{D}\right)$ :

$$
F\left(n_{D}\right)=\left\{n_{\mathrm{D} 1}, n_{\mathrm{D} 2}, \ldots, n_{\mathrm{Di}}\right\}, \quad n_{\mathrm{Di}}>0 .
$$

Days with no lightning are present in the distribution, but we omit these because they do not contribute to our results. This means that the denominator of $N_{D}$ is per thunderstorm day, which we denote here as T-day. The distribution starts from one flash per square per T-day, which is equal to $N_{D}=0.0025$ ground flashes per square kilometer per T-day, and extends to the maximum observed value. Because each of the squares has its own distribution for the daily occurrence of lightning, the percentiles of the distribution describe the rarity of a certain $n_{D}$ value occurring within the square. For example, the 50th percentile of $n_{D}$ (the median) is the 50th percentile value of $n_{D}$ for the distribution of $F\left(n_{D}\right)$. For the purposes of this paper, we study the 50th, 10th, and 1 st percentiles from the complementary cumulative distribution, denoted as $p_{50}\left(N_{D}\right), p_{10}\left(N_{D}\right)$, and $p_{1}\left(N_{D}\right)$, respectively.

Furthermore, the average annual ground flash density $N_{A}$ (ground flashes per square kilometer per year) is the accumulated number of flashes in a square during the study period divided by the number of years and the size of the square, and $N_{A}$ can be expressed with set $F\left(n_{D}\right)$ :

$$
N_{A}=\frac{\sum_{i=1} n_{\mathrm{Di}}}{y \times 400 \mathrm{~km}^{2}}, \quad n_{\mathrm{Di}}>0 .
$$

The average annual number of thunderstorm days in a square, $T_{D}$ (T-days per year), is defined as the number of those days in a square during which lightning has occurred (i.e., $n_{\mathrm{Di}}>0$ ) divided by the number of years $y$.

We have analyzed lightning separately for the United States and Finland, countries that have similar lightninglocation systems. The U.S. National Lightning Detection Network (NLDN) consists of more than a hundred sensors distributed around the United States (Cummins et al. 1998; Cummins and Murphy 2009). The Nordic Lightning Information System (NORDLIS) in northern Europe is a cooperative network consisting of about 30 sensors in Norway, Sweden, Finland, and Estonia (Tuomi and Mäkelä 2008; Mäkelä et al. 2010). Besides its own national sensor data, each of the participating countries also receives the sensor data from the other Nordic countries. Each country processes the sensor data themselves except Estonia, which receives the processed data from the Finnish Meteorological Institute. The NORDLIS cooperation makes possible a wider coverage, better accuracy, and detection efficiency than what would be obtained only with the national networks. NLDN and NORDLIS both use the same sensor type (so-called IMPACT type or its successors manufactured by Vaisala, Inc.), so the data is comparable.

In this study, a ground flash is represented as the first reported stroke. The dataset consists of 103816116 ground flashes between January 2003 and October 2007 from the United States (data from November and December 2007 were not available at the time of the analysis, and their omission from this analysis should not substantively change our results) and 2090348 ground flashes between January 2002 and December 2009 from Finland. Although both networks have been in operation since at least the 1990s, we have selected a shorter, more recent period for this study to ensure the data from both networks is of high quality. Specifically, the choice of the U.S. data starting in 2003 ensures that the data is nearly all within a period after a major upgrade of the network (Cummins and Murphy 2009; Rudlosky and Fuelberg 2010), and full NORDLIS cooperation began in 2002 .

To construct a gridded dataset of daily ground flash density $N_{D}$, the United States and Finland are divided into grids of $20 \mathrm{~km} \times 20 \mathrm{~km}\left(400 \mathrm{~km}^{2}\right)$ squares. The number of analyzed squares is about 50000 in the United States and about 2300 in Finland. We have also converted the lightning data from the original World Geodetic System geographical coordinate system (WGS84) into the kilometer-based Universal Transverse Mercator (UTM) system to provide easier analysis of the data into the $20 \mathrm{~km} \times 20 \mathrm{~km}$ squares. The UTM system makes the orientation of United States different than is typically used (Figs. 1-3, 5, 8, and 9). The total number of flashes within each $20 \mathrm{~km} \times 20 \mathrm{~km}$ square is determined for 
each day in the dataset, where a day is defined from 0000 to 0000 UTC.

Once this analysis is completed, each $20 \mathrm{~km} \times 20 \mathrm{~km}$ square has its own unique distribution $F\left(N_{D}\right)$, which shows how frequently the square experiences thunderstorm days of a certain $N_{D}$. A slightly similar technique has been used in Zipser et al. (2006), who studied the global distribution and occurrence of the most intense thunderstorms. Their satellite-based, optical, total lightning data consisted of both cloud and ground flashes. We will discuss some of their results later in this article, as well as those of Boccippio et al. (2001).

If only one thunderstorm passes over a $20 \mathrm{~km} \times$ $20 \mathrm{~km}$ square during a day, the total distribution of $N_{D}$ at any given square over many years can be viewed as an intensity distribution of individual thunderstorms. This assumption is generally valid in Finland where several storms occurring within one grid square during a day is rare. However, this assumption may be less valid in some regions of the United States that are prone to frequent thunderstorms. Specifically, the life cycle, duration, and extent of storms are likely highly different in the areas in the United States susceptible to the most intense thunderstorms from those in milder locations. Thus, the definition of "the most intense storm" may be difficult to establish. For example, the effect of intense MCSs is clearly shown in our results (Tables 1-2, Figs. 5 and 7; Fritsch and Forbes 2001). Such storms cause several adjacent grid squares to be fully covered by lightning for a long period of time. Especially in these situations, our method does not indicate the intensity of individual thunderstorms but simply the accumulated number of flashes in a square during $24 \mathrm{~h}$. Accounting for the effects of cell motion, the actual position of cells with respect to the grid squares, and the actual duration of the thunderstorms would require different methods, such as cell tracking, but those methods would have their own ambiguities. Thus, we stick with our present method because our primary purpose is not to give statistics of thunderstorms following their motion, but to provide statistics about how different fixed locations experience thunderstorms per day and per year.

\section{Results}

We present maps of the average annual flash density $N_{A}$ (section 3a) and the average annual number of thunderstorm days $T_{D}$ (section $3 \mathrm{~b}$ ) because these parameters have been frequently used in the past. Then, we present maps of some statistics from the distribution of daily ground flash density $N_{D}$ (section $3 \mathrm{c}$ ), which can be related to the intensity of individual thunderstorm days. The annual cycle of $N_{D}$ is presented in section $3 \mathrm{~d}$, and the relationship between $T_{D}$ and $N_{A}$ is explored in section $3 \mathrm{e}$.

\section{a. The average annual ground flash density $\left(N_{A}\right)$}

Values of the largest average annual ground flash density $N_{A}$ exceed 10 flashes per square kilometer per year in Florida and approach 10 flashes per square kilometer per year in the coastal areas near the Gulf of Mexico and in the central parts of the United States (Fig. 1a). A region of moderate values (4-10 flashes per square kilometer per year) extends from Texas northeastward to the Midwest and the Ohio River Valley. In contrast, the western United States and extreme northern areas experience relatively few strikes per year, with values of $N_{A}$ well below 1 flash per square kilometer per year. These results are consistent with previous research displaying the average annual ground flash density over the United States for other time periods [e.g., 1989-91: Plate 4a in Orville (1994); 1992-95: Fig. 3 in Orville and Silver (1997); 1989-96: Fig. 1 in Huffines and Orville (1999); 1995-99: Fig. 7 in Zajac and Rutledge (2001); 1998-2000: Fig. 12 in Orville (2008); 2004-09: Fig. 2a in Rudlosky and Fuelberg (2010)]. Maxima around some urban areas in our data may be due to cloud-to-ground lightning enhancement (e.g., Westcott 1995; Soriano and de Pablo 2002; Naccarato et al. 2003; Kar et al. 2009), although not all areas identified in the literature as having enhancements show up as clearly as others in Fig. 1a. For example, enhancements are apparent in areas near Houston (coordinates $3020 \mathrm{~km} \mathrm{E-630} \mathrm{km} \mathrm{N} \mathrm{in} \mathrm{Fig.} \mathrm{1)} \mathrm{and}$ in southern Louisiana (e.g., Steiger et al. 2002; Steiger and Orville 2003), although only weak enhancements, if any, occur in this dataset for Atlanta (e.g., Stallins et al. 2006; coordinates 3970 km E-1490 km N in Fig. 1).

In Finland, the values of $N_{A}$ are considerably lower (less than 1 flash per square kilometer per year, comparable to the western United States), with the largest values in central and western Finland (Fig. 1b). Lightning enhancements near urban areas seem unlikely to explain these maxima in Finland for three reasons. First, the air is cleaner in general in Finland. Second, the aerosol content in Finland peaks in the late winter and early spring (e.g., Samet et al. 2000; Anttila and Salmi 2006) before the thunderstorm season starts. Third, the most populated and industrialized cities are located in southern Finland. Several studies (e.g., Naccarato et al. 2003; Kar et al. 2007, 2009) have shown a relationship between enhanced cloud-to-ground lightning flashes and PM10 (aerosols smaller than $10 \mu \mathrm{m}$ in diameter), but if this relationship were to hold in Finland, the lightning would be enhanced in the most populated cities in southern Finland where PM10 is largest (Anttila and Salmi 2006). 
(a)

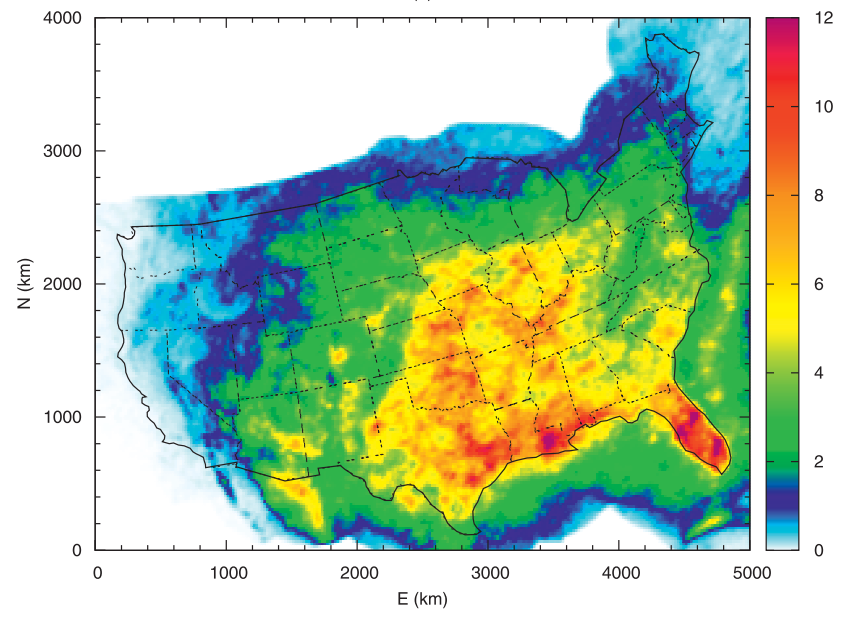

(b)

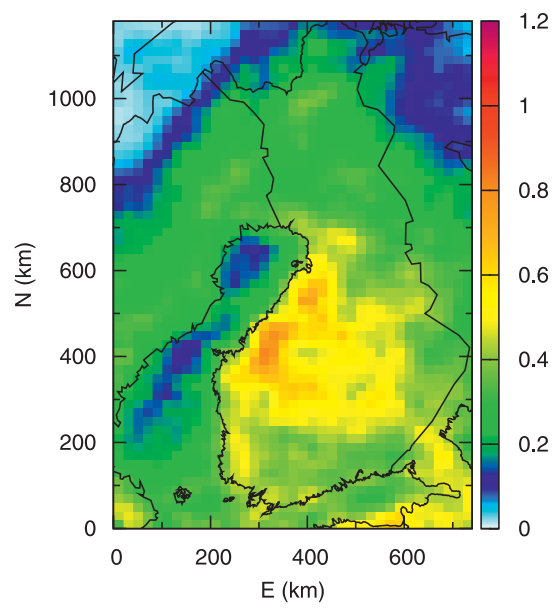

FIG. 1. The average annual ground flash density $N_{A}$ for (a) the contiguous United States and (b) Finland. The units are ground flashes per square kilometer per year. Note the different color scales. In this and subsequent figures, the orientation of the United States is due to the UTM coordinate system.

Although some areas in Finland have comparatively large values of flash density, generally there is no major geographical variation in $N_{A}$ across Finland because of the much smaller area and more homogeneous climate of Finland relative to the United States and because the annual variation in the occurrence of thunderstorms is much greater in Finland than in the United States [cf. Fig. 3 in Tuomi and Mäkelä (2008) and Fig. 2 in Orville and Huffines (1999)], and this variation smoothes the field of $N_{A}$ in Fig. 1b.

\section{b. The average annual number of thunderstorm days}

Figure 2 shows the average number of thunderstorm days per year $T_{D}$ in each $20 \mathrm{~km} \times 20 \mathrm{~km}$ square. Large values (about $100 \mathrm{~T}$-days per year) occur in Florida, near the Gulf of Mexico, and over the southern Rocky Mountains. In contrast, the central and eastern U.S. regions have lower values (30-60 T-days per year). These results are similar to (albeit perhaps a bit larger than) previously published studies of thunderstorm days [e.g., MacGorman et al. (1984), adapted in Fig. 1 of Orville (1991); Fig. 8a in Zajac and Rutledge (2001)] and is similar in shape to the mean annual flash hours in Huffines and Orville (1999, their Fig. 2), except for a maximum in eastern Oklahoma and Kansas not reproduced in Fig. 2a.

Comparing Figs. 1a and 2a suggests that (i) the large $N_{A}$ values in Florida and near the Gulf of Mexico are mainly due to the larger number of days with thunderstorms, and (ii) the large $N_{A}$ values in the central and eastern U.S. regions are the consequence of more intense thunderstorms, but fewer thunderstorm days per year.

In Finland (Fig. 2b), about 12-15 T-days per year occur throughout the whole country, except for the northernmost parts, which show smaller values $(<10$ T-days per year) as a result of the shorter summer season. Similar values of the annual number of thunderstorm days are found in a global map published by the World Meteorological Organization in 1956 [reproduced as Fig. 2.8 in Rakov and Uman (2003, p. 36)].

\section{c. The daily ground flash density $\left(N_{D}\right)$}

To show the distributions of daily ground flash density for each of about 50000 squares in the United States would be excessive. Instead, we consider four distinct climatological regions of the United States: western, central, eastern, and Florida (Fig. 3). The surface area of each region is the same $\left(800000 \mathrm{~km}^{2}\right)$. For Florida, the data from grid squares over the land and the surrounding waters are calculated separately to see any differences between storms over land and over water. Although NLDN detection efficiency starts to decrease over the water because of the decreasing sensor density (Cummins and Murphy 2009), we believe the effect on our results is small. Figures $4 a-e$ show the distributions of $N_{D}$ for all of Finland and each of the four regions in the United States. All of the curves have slightly different features, as can be seen from the $x$-axis intercepts. The distributions for regions with less frequent thunderstorms (western United States and Finland) do not reach the extremely large $N_{D}$ values (5-10 flashes per square kilometer per year, Figs. 4a,e). For comparison, the distributions of $N_{D}$ values for U.S. regions with more frequent thunderstorms (central, eastern, and Florida) have much larger values of $N_{D}$ (Figs. $4 \mathrm{~b}-\mathrm{d}$ ). Over Florida, the distributions over land and water show that 
(a)

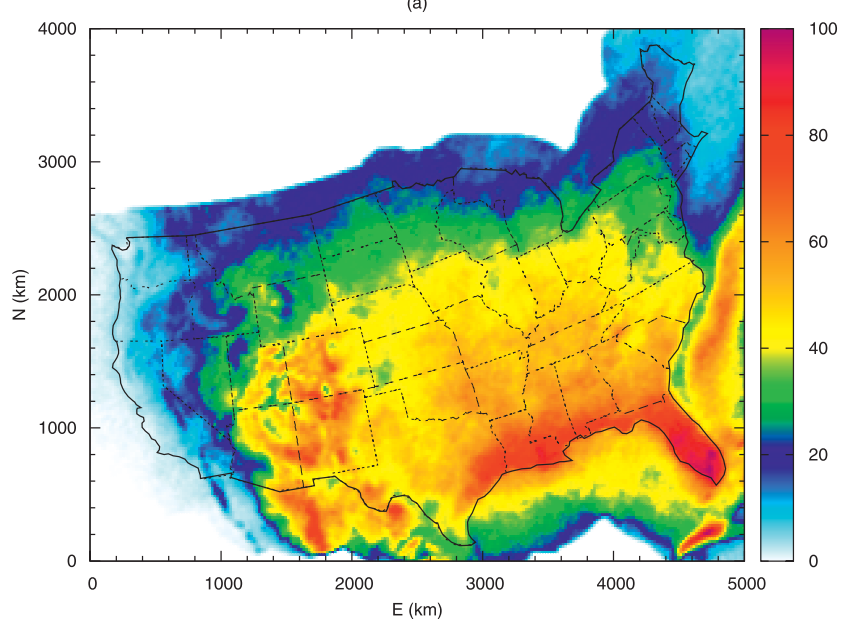

(b)

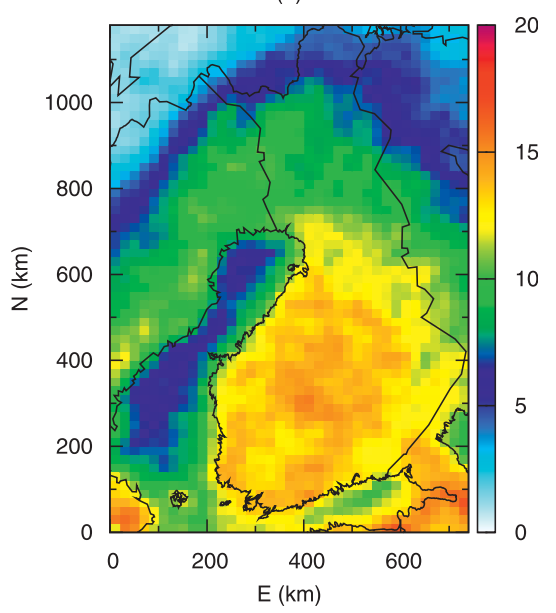

FIG. 2. The average annual number of thunderstorm days $T_{D}$ for (a) the contiguous United States and (b) Finland. The units are T-days per year. Note the different color scales.

the largest $N_{D}$ values during the study period have occurred over the water, but generally the land areas experience the most intense storms (Fig. 4d).

To compare these five graphs directly, these data can be plotted as complementary cumulative frequency distributions, where the values along the $y$ axis indicate the percentage of thunderstorm days during which a certain value of $N_{D}$ is exceeded (Fig. 4f).

The median values (50\% on the $y$ axis) for each region are about $0.01-0.03$ flashes per square kilometer per T-day (Fig. 4f; Table 1), which means that in all regions most days with thunderstorms feature relatively weak storms. However, for smaller percentages (i.e., more intense thunderstorms), the complementary cumulative curves are more dissimilar to each other. For example, the densities at $10 \%, p_{10}\left(N_{D}\right)$, range from 0.06 flashes per square kilometer per T-day in Finland to 0.30 flashes per square kilometer per T-day in the central U.S. region, and the densities at $1 \%, p_{1}\left(N_{D}\right)$, range from 0.23 flashes per square kilometer per T-day in Finland to 1.27 flashes per square kilometer per T-day in the central U.S. region (Fig. 4f; Table 1). These percentages mean that, in the central U.S. region, for example, $1 \%$ of thunderstorm days produce a daily ground flash density $N_{D}$ of 1.27 flashes per square kilometer per T-day or higher.

Table 1 shows the median, $10 \%, 1 \%$, and maximum $N_{D}$ values for each region. Interestingly, the greatest observed value in Florida, which occurred on 26 April 2003 , is larger over the water than over the land, and this square is located just off the coast (at $840 \mathrm{~km}$ N-4280 km E in Figs. 1, 2, 3, 5, and 8). Seity et al. (2001) found that most of the thunderstorms over the water develop close to the coastline in France. The thunderstorm climate of Estonia also shows more frequent lightning over the water near the coast during intense frontal thunderstorms (Enno 2010).

The highest observed value of $N_{D}$ across the United States occurred within a $20 \mathrm{~km} \times 20 \mathrm{~km}$ square in northern Kansas on 23 June 2003 (at 1760 km N-2480 km E in Figs. 1, 2, 3, 5, and 8). The value was 13.19 flashes per square kilometer per T-day and resulted from 5276 located ground flashes. This day featured a nearly stationary mesoscale convective system that produced 15 tornadoes in Kansas and Nebraska, as well as numerous severe-hail reports (see online at http://www.spc.noaa.gov/ climo/reports/030622_rpts.html).

Figure 5 maps the values of $p_{1}\left(N_{D}\right)$ in the United States and Finland. Although Fig. 5 can be drawn for any percentile, regional differences would be diminished for

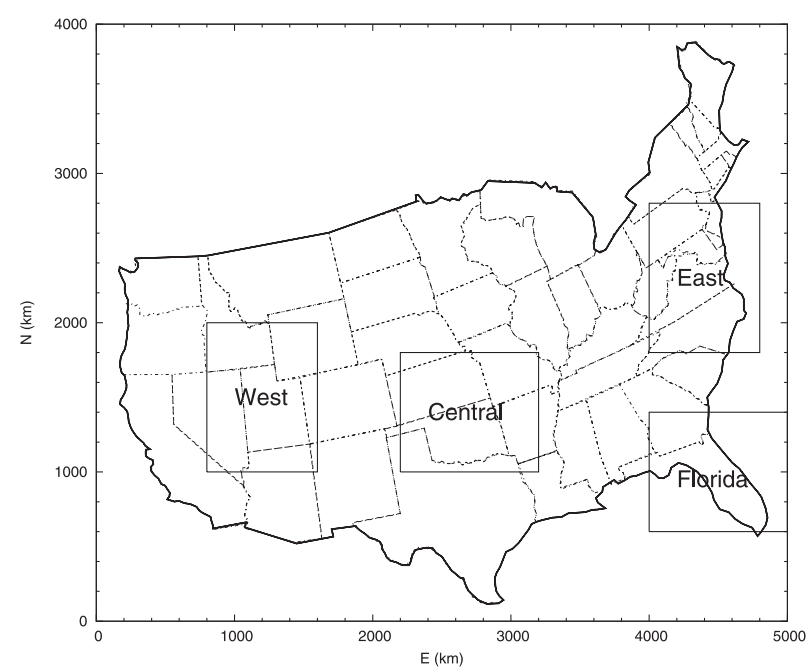

FIG. 3. The four regional divisions of the United States used in the analysis of Figs. 4, 6, and 7. 
(a)

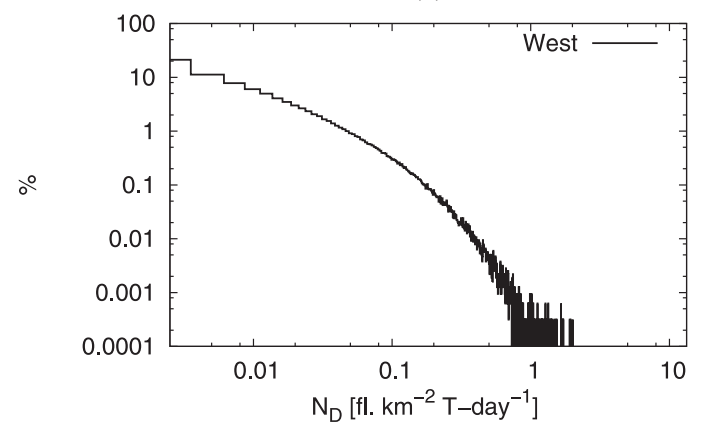

(c)

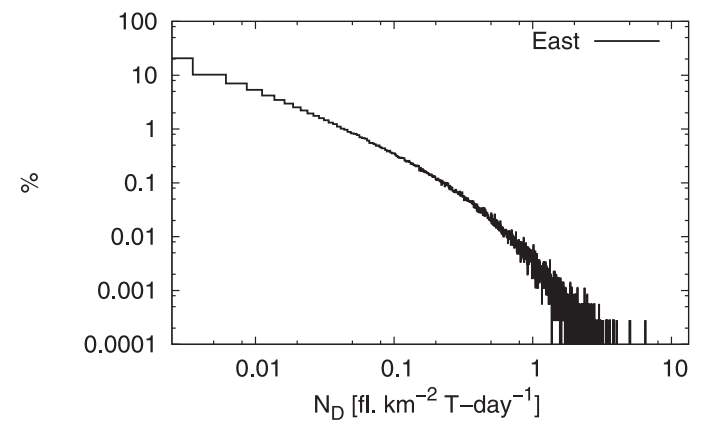

(e)

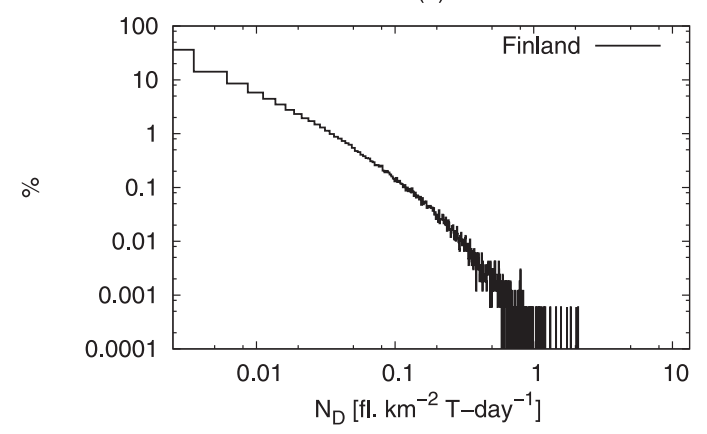

(b)

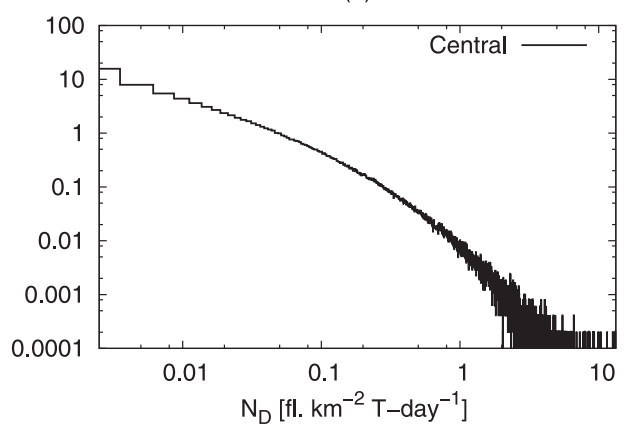

(d)

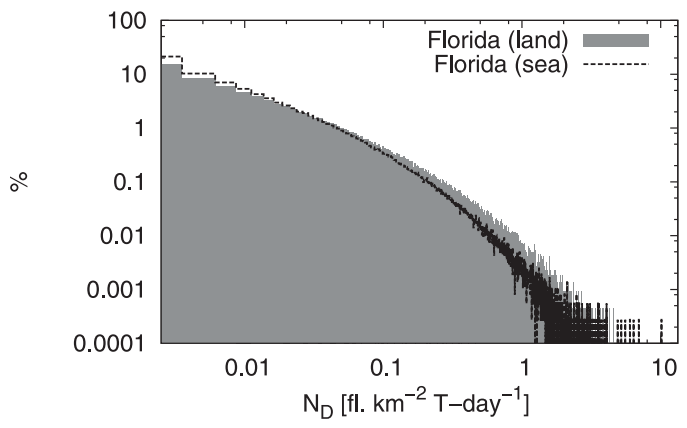

(f)

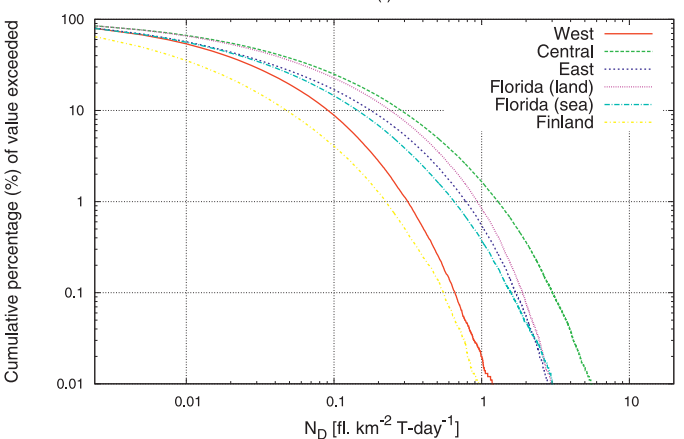

FIG. 4. Distributions of $N_{D}$ for (a)-(d) different regions in the United States (shown in Fig. 3) and (e) for Finland. (f) The complementary cumulative distributions for the five regions in (a)-(e). The $x$ axis starts from 0.0025 (i.e., 1 flash in a $20 \mathrm{~km} \times 20 \mathrm{~km}$ square per day).

larger percentages as the curves in Fig. $4 \mathrm{f}$ become closer together. For example, $p_{50}\left(N_{D}\right)$ would have little spatial variation, as is apparent from the similarity of the $50 \%$ values for each region (Table 1).
In the United States, the largest values of $p_{1}\left(N_{D}\right)$ occur along the arc from Texas to the Midwest (Fig. 5a). Florida has much lower values (Fig. 5a), which suggests that on average individual thunderstorm days are not as

TABLE 1. Some statistics of the complementary cumulative distributions of daily ground flash densities for regions shown in Fig. 3 and for Finland. The two values for Florida are for land and water areas. Units are flashes per square kilometer per T-day.

\begin{tabular}{|c|c|c|c|c|}
\hline Region & $p_{50}\left(N_{D}\right)$ & $p_{10}\left(N_{D}\right)$ & $p_{1}\left(N_{D}\right)$ & Max \\
\hline Central United States & 0.03 & 0.30 & 1.27 & 13.19 \\
\hline Florida (land) & 0.03 & 0.25 & 0.93 & 4.57 \\
\hline Florida (water) & 0.02 & 0.16 & 0.65 & 10.15 \\
\hline Eastern United States & 0.02 & 0.19 & 0.77 & 6.50 \\
\hline Western United States & 0.01 & 0.10 & 0.61 & 2.02 \\
\hline Finland & 0.01 & 0.06 & 0.23 & 2.10 \\
\hline
\end{tabular}


(a)

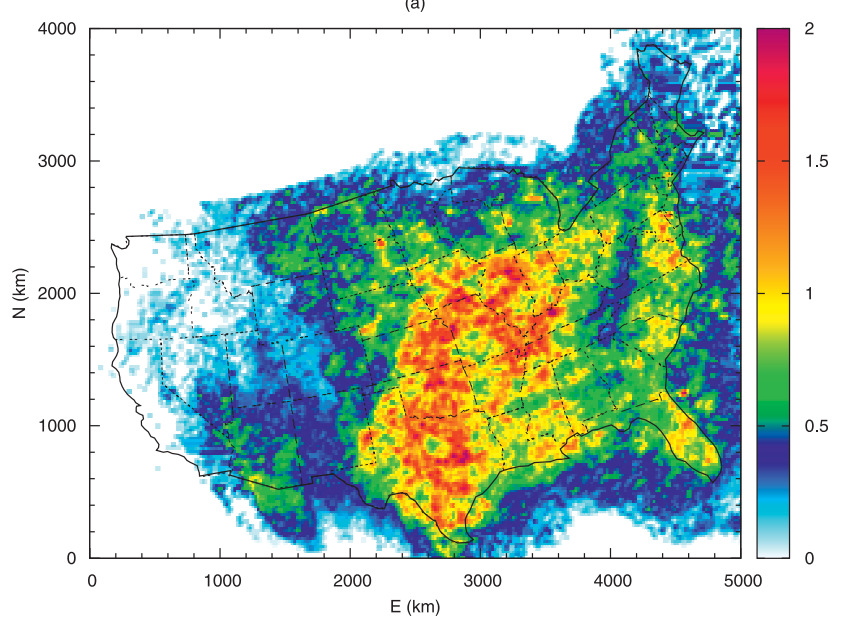

(b)

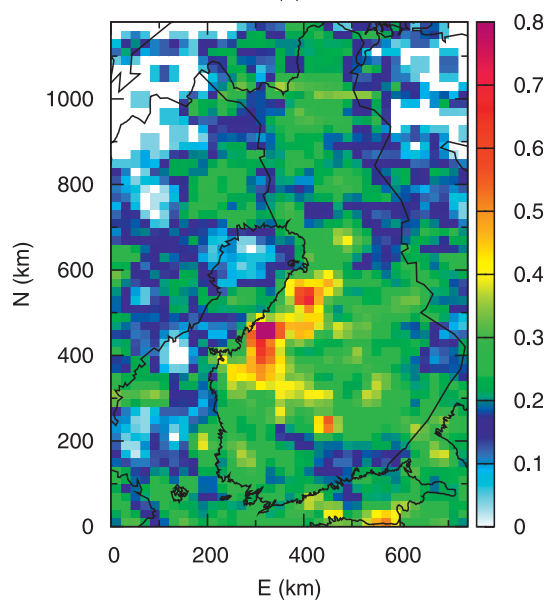

FIG. 5. The $p_{1}\left(N_{D}\right)$ ground flash density values for (a) the contiguous United States and (b) Finland. The units are ground flashes per square kilometer per T-day. Note the different color scales.

intense there compared to the central U.S. region, despite the large number of flashes and thunderstorm days in Florida (Figs. 1a and 2a). Zipser et al. (2006) studied the occurrence of the most intense thunderstorms in the tropics using data from satellite-based sensors. Their Figs. 3 and 6a,b show that intense thunderstorms are relatively frequent in the central U.S. region compared to Florida, consistent with our results. Also, the storms in the central U.S. region show similar or larger number of total flashes (intracloud plus cloudto-ground flashes) per storm than in Florida (Boccippio et al. 2001). However, because large mesoscale convective systems are the main source of intense lightning in the central U.S. region (Houze 2004), high accumulation of flashes occur in the grid squares in those areas, compared to the smaller thunderstorms common over Florida. Therefore, it is not fair to say that thunderstorms are more intense in the central United States than in Florida, but rather that individual thunderstorm days produce more lightning over a fixed location during a 24-h period.

In Finland, $p_{1}\left(N_{D}\right)$ values are much smaller and there are no major gradients, except along the western coast of Finland near the Gulf of Bothnia (Fig. 5b). This enhancement may be related to coastal effects, such as the sea-breeze convergence, during suitable conditions for intense thunderstorms. Anecdotal evidence seems to indicate local enhancement in this area, especially during several consecutive days in 2003 when intense storms developed near the coastline of western Finland. The storms moved quite slowly to the east and caused locally high ground flash densities. This kind of intense thunderstorm development is not common in Finland, suggesting a topic for further research.

\section{d. Annual cycle of the daily ground flash density $\left(N_{D}\right)$}

The monthly distributions of $p_{1}\left(N_{D}\right)$ and all ground flashes for each region are shown in Fig. 6. If the $p_{1}\left(N_{D}\right)$ curve (solid line) has a larger percentage than the "all" curve (dashed line), then a large number of ground flashes during that month are produced by the most intense storms. The annual cycle of $N_{D}$ is broadly similar in all regions; the percentages increase starting from early summer, peak in July-August, and decrease toward the autumn. The central U.S. region has a broad peak with a June maximum (Fig. 6b). The midsummer peak is most pronounced in the western United States and Finland, and is even narrower in Finland, indicating the shorter season for thunderstorms (Figs. 6a,f). However, in Finland (Fig. 6f), the percentage of $p_{1}\left(N_{D}\right)$ is larger in May than in June, which suggests that during the study period (2002-09), June atmospheric conditions have not been favorable for intense thunderstorms, although more ground flashes occur on average in June than in May (Tuomi and Mäkelä 2008). Indeed, Tuomi and Mäkelä (2008) showed that the Finnish thunderstorm season does not start gradually, but rather with a few intense thunderstorm days in May, before a period in June of less intense thunderstorms. This decrease in the intensity of Finnish thunderstorms in June is supported by the 1930-2006 large-hail climatology of Tuovinen et al. (2009, their Fig. 3). They found that more large hail (2.0$3.9 \mathrm{~cm}$ in diameter) falls in June than in May, but the occurrence of very large hail (at least $4.0 \mathrm{~cm}$ in diameter) is more common during the last two weeks of May than during the first two weeks of June. In several studies summarized in Williams (2001), the occurrence of large hail is noted to accompany copious lightning. We must 

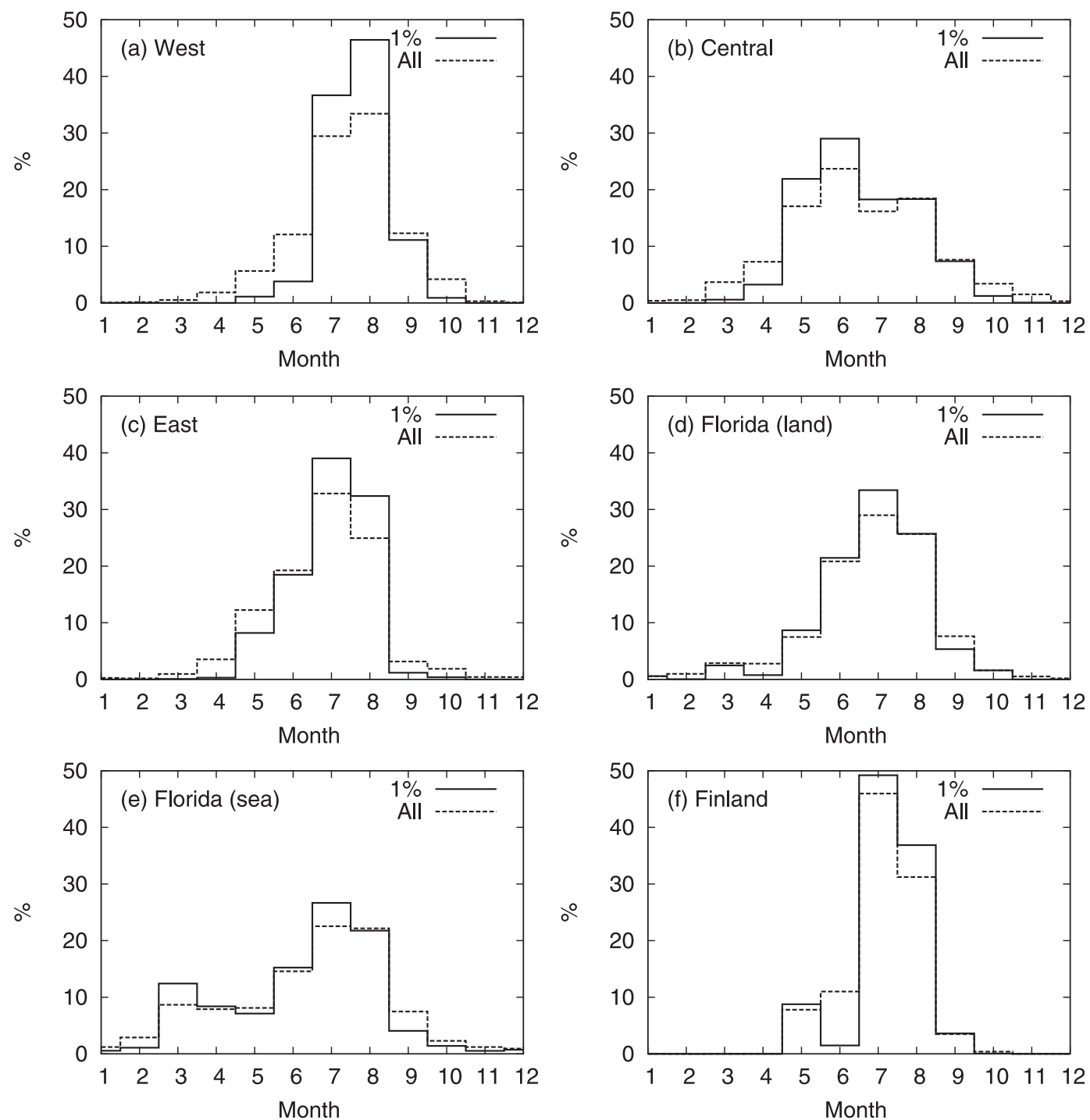

FIG. 6. The monthly distributions of the $p_{1}\left(N_{D}\right)$ ground flash density values. See also Table 1.

emphasize, however, that the large annual variation of convective storms and their less frequent occurrence in Finland means comparing different studies over different time periods may produce differing results.

In the central United States and Florida (Figs. 6b,d,e), the distributions are broader throughout the year, supporting the well-known fact that intense storms are common in March-April and as late as SeptemberOctober. Comparing the solid and dashed lines in Fig. 6, all areas show that the percentages of the $p_{1}\left(N_{D}\right)$ (solid) are larger than the percentage of all flashes (dashed) in the midsummer and lower in the early and late summer. Thus, a large fraction of midsummer flashes are from very intense storms. In the Florida land region (Fig. 6d), this feature is not so well pronounced, indicating that the large percentage of ground flashes is not so dependent on the most intense storms, but the high number of thunderstorms, in general.

\section{e. The relationship between $T_{D}$ and $N_{A}$}

Following previous work summarized in Rakov and Uman (2003, p. 35), Fig. 7 shows the relationship between the average annual number of thunderstorm days, $T_{D}$, and the average annual ground flash density, $N_{A}$, for the whole U.S. and Finnish datasets, as well as the four regions of the United States separately. As Rakov and Uman (2003) discuss, this relationship can be used to estimate $N_{A}$ globally because $T_{D}$ data has been collected for decades all around the world. Despite the considerable scatter in plots such as Fig. $7, N_{A}$ can be 


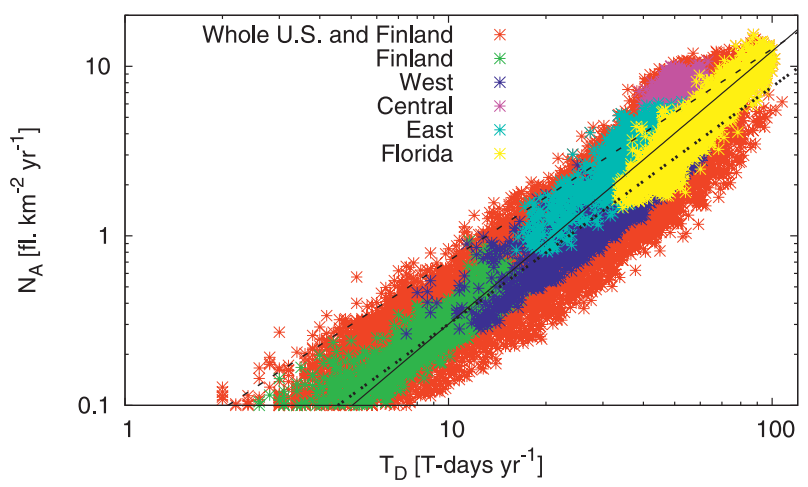

FIG. 7. Scatterplot showing the relationship between $T_{D}$ and $N_{A}$ for all of the $20 \mathrm{~km} \times 20 \mathrm{~km}$ squares in the United States and Finland (red) with the regional data points in different colors. The solid line is the least squares fit for all the U.S. and Finnish data $N_{A}=0.007 T_{D}^{1.61}$, and the two other fits are $N_{A}=0.04 T_{D}^{1.25}$ (Anderson et al. 1984, dashed), and $N_{A}=0.012 T_{D}^{1.40}$ (Kuleshov and Jayaratne 2004, dotted). Table 2 shows the regional fit equations.

estimated in areas where modern lightning-location systems are not available.

The most common way to apply a fit to this data is through a linear least squares regression method in log$\log$ space to an equation of the form $N_{A}=a T_{D}^{b}$. The coefficients $a$ and $b$ have been calculated from the data. However, as the actual relationship between $T_{D}$ and $N_{A}$ is not linear, any correlation coefficient is valid only in $\log -\log$ space. The best regression model fit to all of the U.S. and Finnish data has the form $N_{A}=0.007 T_{D}^{1.61}$ (solid line in Fig. 7), with the linear correlation coefficient $r=0.97$. Figure 7 also shows two other previously published regression lines for Australia $\left(N_{A}=0.012 T_{D}^{1.4}\right.$; Kuleshov and Jayaratne 2004) and for South Africa $\left(N_{A}=0.04 T_{D}^{1.25}\right.$; Anderson et al. 1984). The Australian dotted line more closely matches the data in Fig. 7 for smaller $T_{D}$, whereas the South African dashed line more closely matches the data for larger $T_{D}$. The different lines and their relationship to our dataset suggest the limited applicability of curves outside of the area for which they were calculated.

This point is further emphasized when data from the different regions in our dataset are displayed as different colored symbols in Fig. 7. Table 2 displays the regional regression model fits and statistics of each of the regional datasets, showing quite a bit of variability among the regions. Florida (yellow) has the largest average values of $N_{A}$ and $T_{D}$ (averages of the squares of Florida are 8.2 flashes per square kilometer per year and 80.1 T-days per year), whereas the central U.S. region (purple) has lower values (averages are 6.1 flashes per square kilometer per year and $48.7 \mathrm{~T}$-days per year). However, more ground flashes occur per thunderstorm day in the central U.S. region on average, as shown by the differences in the regression model equations of the different regions and by $N_{A}$ divided by $T_{D}$. In Finland (green), the average values of $N_{A}$ and $T_{D}$ are small (Table 2), which can be related to the short thunderstorm season at these higher latitudes $\left(60^{\circ}-70^{\circ} \mathrm{N}\right)$. In the western U.S. region (blue), the average values are close to Finland, but in the eastern U.S. region (cyan), the average values are considerably larger (Table 2).

These results can be shown more clearly if we define an average increase rate for each regional curve as

$$
\frac{N_{\mathrm{Amax}}-N_{\mathrm{Amin}}}{T_{\mathrm{Dmax}}-T_{\mathrm{D} \min }}
$$

If the value of this rate of rise is large, it means that only a small increment in $T_{D}$ causes a relatively large increase in $N_{A}$, which is an obvious result in the region where intense thunderstorms occur. The values of this increase rate for each region are shown in Table 2. The central U.S. region has the largest value ( 0.22 flashes per square kilometer per T-day), indicating that a given annual ground flash density is obtained with fewer thunderstorm days, and Finland has the smallest value (0.03 flashes per square kilometer per T-day).

If $N_{A}$ is divided by $T_{D}$, the resulting quantity measures the average ground flash density per thunderstorm day (Fig. 8). This quantity further indicates the differences of thunderstorm days in different geographical locations. In the United States, the largest values are found in the region extending from Texas to Iowa-Illinois (about 0.2 flashes per square kilometer per T-day) and

TABLE 2. Regression models and the average increase rate for the different regions in Fig. 7.

\begin{tabular}{|c|c|c|c|c|c|}
\hline Region & $\begin{array}{l}\text { Regression } \\
\text { model }\end{array}$ & $r$ & $\begin{array}{c}\operatorname{Avg} T_{D} \\
\text { (T-days per year) }\end{array}$ & $\begin{array}{c}\operatorname{Avg} N_{A} \\
\text { (flashes per square } \\
\text { kilometer per year) }\end{array}$ & $\begin{array}{l}\text { Avg increase rate } \\
\text { (flashes per square } \\
\text { kilometer per T-day) }\end{array}$ \\
\hline Central United States & $N_{A}=0.005 T_{D}^{1.81}$ & 0.67 & 48.7 & 6.1 & 0.22 \\
\hline Florida (land) & $N_{A}=0.004 T_{D}^{1.71}$ & 0.80 & 80.1 & 8.2 & 0.17 \\
\hline Florida (water) & $N_{A}=0.003 T_{D}^{1.76}$ & 0.84 & 50.4 & 3.5 & 0.13 \\
\hline Eastern United States & $N_{A}=0.024 T_{D}^{1.33}$ & 0.79 & 38.2 & 3.1 & 0.10 \\
\hline Western United States & $N_{A}=0.013 T_{D}^{1.36}$ & 0.91 & 31.8 & 1.5 & 0.06 \\
\hline Finland & $N_{A}=0.019 T_{D}^{1.20}$ & 0.96 & 9.2 & 0.3 & 0.03 \\
\hline
\end{tabular}


(a)

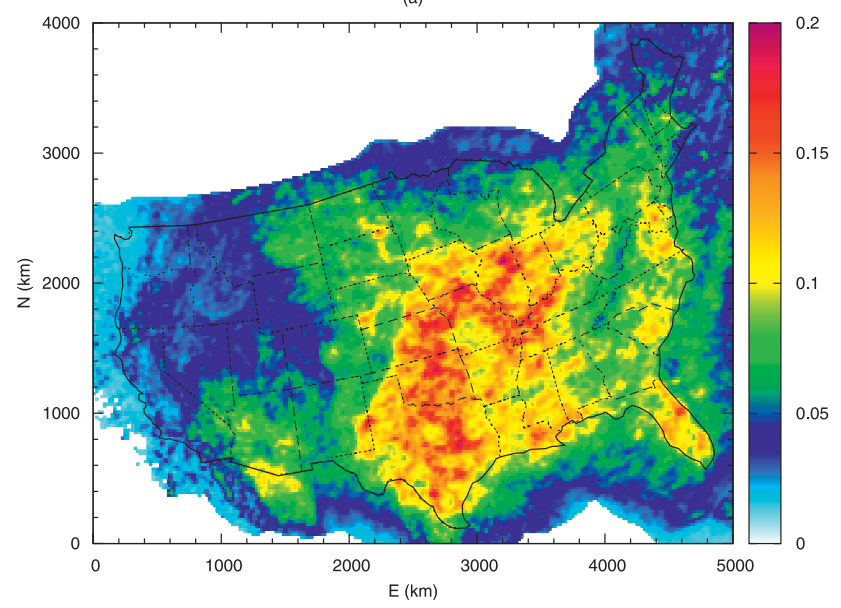

(b)

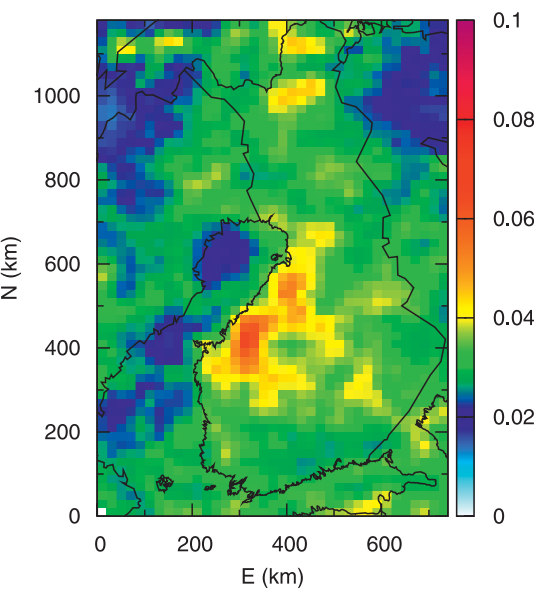

FIG. 8. The ratio between the average annual ground flash density $N_{A}$ and the average annual thunderstorm day number $T_{D}$ (in ground flashes per square kilometer per T-day) for (a) the contiguous United States and (b) Finland.

in Florida (about 0.15 flashes per square kilometer per T-day). The value over Finland is nearly constant at around 0.03 flashes per square kilometer per T-day, and the largest value is only 0.08 flashes per square kilometer per T-day. However, the values in northern Finland are similar to those in southern Finland, indicating that, despite the shorter thunderstorm season in the north, individual thunderstorm days do not differ much across Finland.

To further strengthen the results based on Figs. 5 and 8 , we also have analyzed the maximum observed daily ground flash density in the United States and Finland during the study period (Fig. 9). Figure 9 shows that the greatest values are found in the same areas that also stand out in Figs. 5 and 8 (i.e., in the central parts of United States and Florida, and in the western parts of Finland). In principle, Fig. 9 is more prone to random variation compared to Figs. 5 and 8 , because an extremely large value may occur in an area that does not generally experience large ground flash density values. For example, larger values of maximum observed daily ground flash density occur over the water than over the land in Fig. 9, although the daily ground flash density values are generally larger over the land (Figs. 5 and 8 ).

To summarize this section, although there are large differences in the number of thunderstorm days and in the annual average ground flash density between different regions in our dataset, our method provides a way to see how the annual accumulation of ground flashes is achieved. Furthermore, the local number of thunderstorm days can be used to explain the annual ground flash density. However, the method used here does not consider the differences in the thunderstorm characteristics in various regions (e.g., extent and actual duration), which, although important, requires further study.

\section{Applications of daily flash density}

There are different kinds of lightning-location systems worldwide, both ground based and satellite based, from which some are able to detect primarily ground lightning and some total lightning (i.e., intracloud flashes plus ground flashes). Our method of determining the daily ground flash density is applicable to any system with ground flash data and a detection efficiency high enough or known. A similar method may be applied to total lightning data, but the present coverage of total lightning systems is limited compared to ground lightning networks. As satellite-based lightning imagers will be launched into geostationary orbit in the coming years (e.g., Christian et al. 1989; Stuhlmann et al. 2005), a nearglobal analysis will be possible. However, as the satellitebased detectors measure total lightning, the statistics computed from satellite using total lightning flashes may be different from the statistics computed from groundbased networks using ground flashes.

An interesting extension to this study would be to include data from central Africa, South America, and Indonesia, which are regions of large ground flash density with a large number of intense events (Rodger et al. 2006; Zipser et al. 2006). The results would quantify the intensity of the thunderstorms there and indicate if the large ground flash density values in these areas are due to moderate but almost constant thunderstorm activity per year or due to a short thunderstorm season with extremely intense thunderstorm days. The results would also serve as a further test of Zipser et al.'s (2006) results, showing where the most intense thunderstorms on the earth are found.

The results of this study can be used to quantify the intensity of individual thunderstorms. Once the distribution of $N_{D}$ for a given area is known, the distribution can be 
(a)

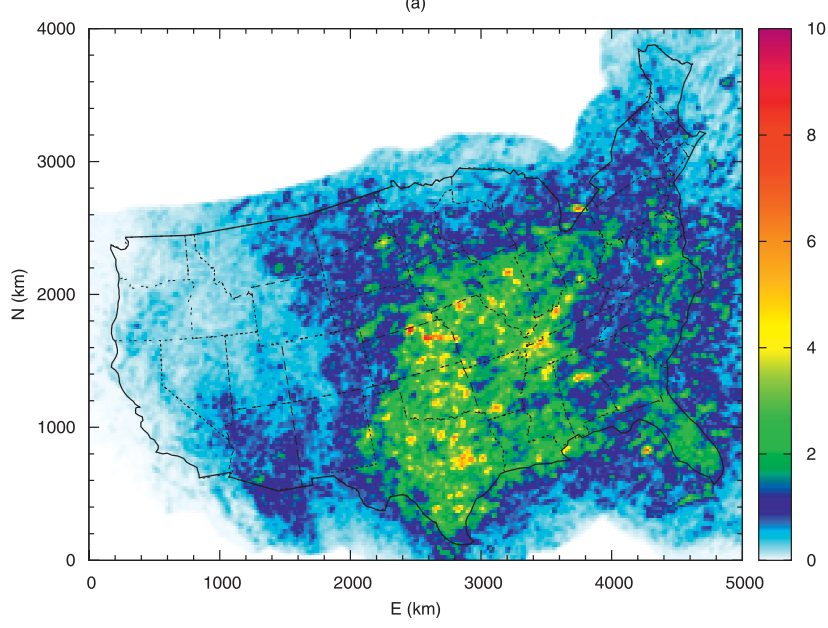

(b)

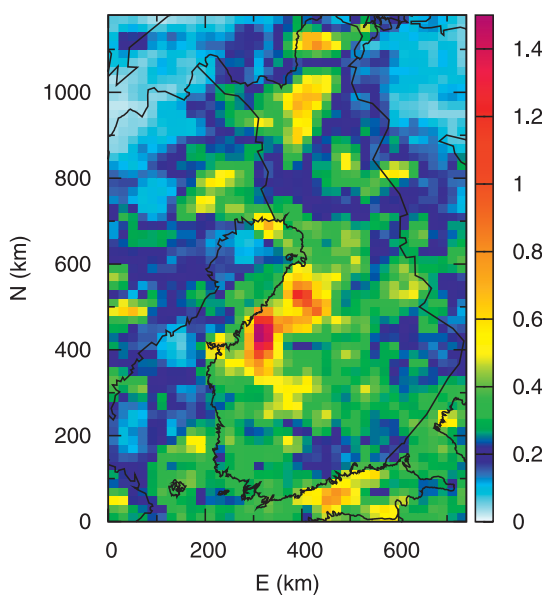

FIG. 9. The maximum observed daily ground flash density $\left(N_{D}\right)$ for (a) the contiguous United States and (b) Finland. The units are ground flashes per square kilometer per T-day.

used to create an intensity scale according to the rarity of a certain ground flash density. For example, if $N_{D}$ exceeds the $1 \%$ percentile density value, on a statistical basis we could classify the storm for example as "exceptionally intense" because of the rarity of such an $N_{D}$ value occurring.

Indeed, at the Finnish Meteorological Institute, we have tested a real-time five-scale intensity classification product based on the method presented in this paper (Table 3). Ground flash densities are classified into five classes from least intense (L1) to most intense (L5; Table $3)$. We have created this classification so that the least intense class constitutes $88 \%$ of all daily ground flash densities from the complementary cumulative distribution of Fig. 4f, the two most intense levels (L4 and L5) constitute $1 \%$, and the most intense level (L5) constitutes only $0.02 \%$ from the distribution. These last two choices are to ensure that when such a large value is exceeded, it can be fairly classified as an extremely rare thunderstorm.

In real time, as the number of ground flashes increases in a grid square, the product displays the increasing intensity of the storm at that grid square. An example of how this product works is shown from 10 July 2006 (Fig. 10). Figure 10a shows the traditional lightning product showing each flash as an individual location. Although lightning has occurred over much of southern and eastern Finland, it is difficult to give an objective answer about the intensity of the lightning merely from this figure.

Figure 10b shows the same lightning data, but now plotted as $N_{D}$ according to the method presented in this article. The data are analyzed on $20 \mathrm{~km} \times 20 \mathrm{~km}$ squares, and the values on each square and the colors of each square indicate the ground flash density in flashes per 100 kilometers squared (to plot the values in whole numbers rather than decimal values).
This product is useful for nowcasting, because a forecaster sees in real time how the intensity of lightning is developing and in what directions the most intense storms are moving. Also, archived daily maps can be used to pinpoint areas of intense lightning for later scientific or forensic research. When these data are imported into Geographical Information System (GIS) software, properties of the grid squares (e.g., population density) can also be visualized.

\section{Conclusions}

A method to quantify the intensity of individual thunderstorm days according to ground flashes has been developed. The intensity of a thunderstorm is defined as the daily ground flash density, $N_{D}$, calculated on a $20 \mathrm{~km} \times 20 \mathrm{~km}$ fixed square. The square size has been chosen because it roughly corresponds to the typical size of a thunderstorm cell. The lightning observations are based on a lightning-location system, and the analysis covers the United States and Finland. If only one thunderstorm moves over a square during a given day, our

TABLE 3. The ground lightning intensity classification used at the Finnish Meteorological Institute. The last column indicates the percentage value of the intensity level from the complementary cumulative distribution in Fig. $4 \mathrm{f}$

\begin{tabular}{ccc}
\hline \hline Classification & $\begin{array}{c}\text { Ground flash density } \\
\text { (flashes per square } \\
\text { kilometer per T-day) }\end{array}$ & $\begin{array}{c}\text { Percentage } \\
(\%)\end{array}$ \\
\hline L5 & $N_{D}>0.8$ & 0.02 \\
L4 & $0.25<N_{D} \leq 0.8$ & 0.98 \\
L3 & $0.08<N_{D} \leq 0.25$ & 5.0 \\
L2 & $0.025<N_{D} \leq 0.08$ & 6.0 \\
L1 & $0<N_{D} \leq 0.025$ & 88.0 \\
\hline
\end{tabular}



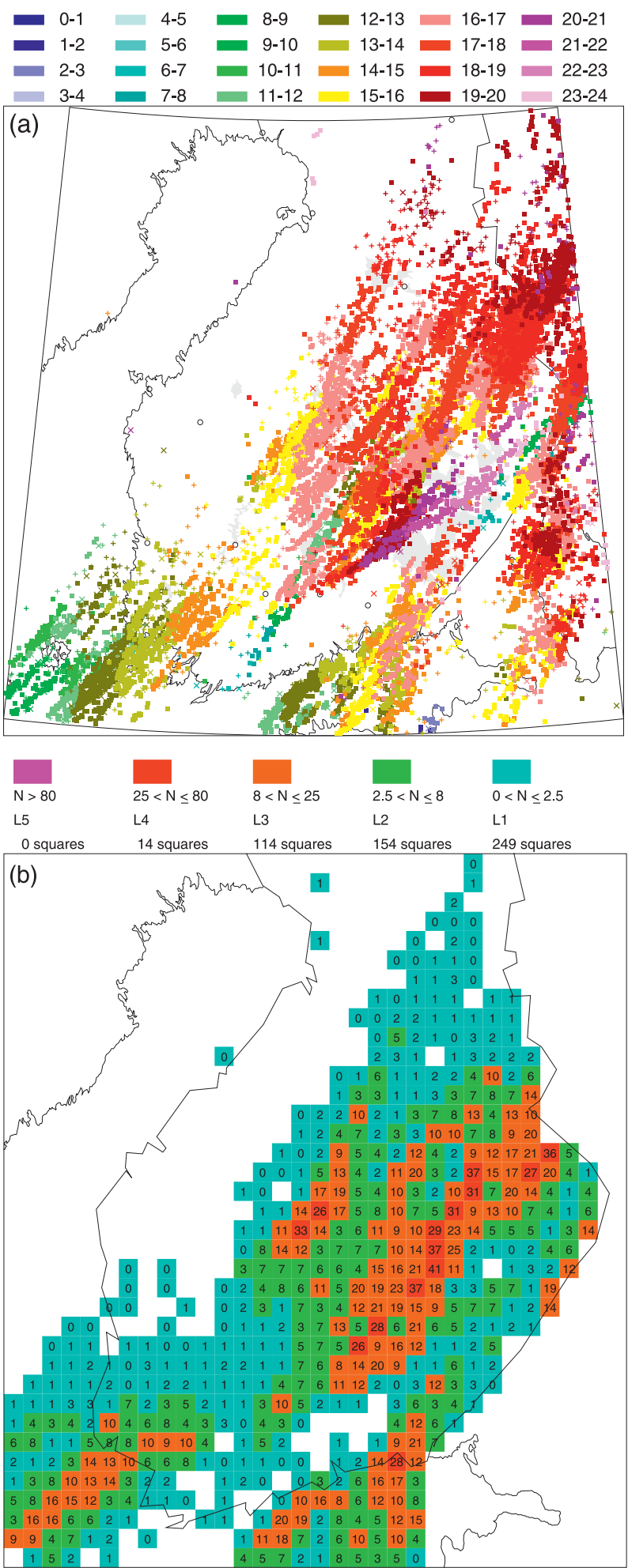

FIG. 10. (a) The 12189 ground flashes across Finland on $10 \mathrm{Jul}$ 2006. The inset color table indicates the UTC hour of the flashes $(\mathrm{LST}=\mathrm{UTC}+3 \mathrm{~h})$. (b) Daily ground flash density map (flashes per 100 kilometers squared per T-day) showing the intensity of lightning in five classes (L1-L5). results can be related to the intensity of individual thunderstorms (i.e., the flashes accumulated in a square during a day from a single storm). This assumption works well in Finland, but may not work as well in other locations where multiple storms may pass over a given area during one day.

The motivation for this paper is to show the distribution of the daily ground flash density in different areas, and especially the fraction and rarity of those storms that produce extremely large numbers of flashes. The distributions of $N_{D}$ show that the majority of storms are relatively weak regardless of location: the $50 \%$ (median) value in the distribution is $0.01-0.03$ ground flashes per square kilometer per T-day. However, the distributions of $N_{D}$ show large differences for the larger values of ground flash density. For example, in the central U.S. region, $1 \%$ of storms produce flash densities exceeding 1 ground flash per square kilometer per T-day, whereas, in Finland and the western U.S. region, the $1 \%$ value is about 0.2 ground flash per square kilometer per T-day.

An important result from this study is that the daily ground flash density can show that some areas receiving a large annual number of ground flashes are the result of a large number of weak to moderate storms over a longer season (e.g., Florida and the southern United States along the Gulf of Mexico), not the result of a few intense storms that produce copious lightning. Such a conclusion cannot be reached from the average annual flash density $N_{A}$ distributions alone, which do not consider the thunderstorm days individually.

Acknowledgments. We are extremely grateful to Tapio J. Tuomi, Professor Emeritus at the Finnish Meteorological Institute, who first developed the concept of this paper. We thank the NOAA/National Severe Storms Laboratory for providing the U.S. lightning data and Gregory Carbin of the Storm Prediction Center for providing the criteria for severe thunderstorms in the United States. We thank three anonymous reviewers of an earlier version of this manuscript for their comments, as well as the reviewers of this version. Schultz is partially funded by Vaisala Oyj. This study is part of a Finnish INTO-project funded by the Finnish Funding Agency for Technology and Innovation (Tekes).

\section{REFERENCES}

Anderson, R. B., H. Kroninger, H. R. Niekerk, and D. W. Meal, 1984: Development and field evaluation of a lightning earthflash counter. IEE Proc., 131A, 118-124.

Antonescu, B., and S. Burcea, 2010: A cloud-to-ground lightning climatology for Romania. Mon. Wea. Rev., 138, 579-591.

Anttila, P., and T. Salmi, 2006: Characterizing temporal and spatial patterns of urban PM10 using six years of Finnish monitoring data. Boreal Environ. Res., 11, 463-479. 
Areitio, J., A. Ezcurra, and I. Herrero, 2001: Cloud-to-ground lightning characteristics in the Spanish Basque Country area during the period 1992-1996. J. Atmos. Sol.-Terr. Phys., 63, $1005-1015$

Biagi, C. J., K. L. Cummins, K. E. Kehoe, and E. P. Krider, 2007: National Lightning Detection Network (NLDN) performance in southern Arizona, Texas, and Oklahoma in 2003-2004. J. Geophys. Res., 112, D05208, doi:10.1029/2006JD007341.

Boccippio, D. J., K. L. Cummins, H. J. Christian, and S. J. Goodman, 2001: Combined satellite- and surface-based estimation of the intracloud-cloud-to-ground lightning ratio over the continental United States. Mon. Wea. Rev., 129, 108-122.

Byers, H. R., and R. R. Braham, 1949: The Thunderstorm. U.S. Department of Commerce, $287 \mathrm{pp}$.

Christian, H. J., R. J. Blakeslee, and S. J. Goodman, 1989: The detection of lightning from geostationary orbit. J. Geophys. Res., 94, 13 329-13 337.

—_, and Coauthors, 2003: Global frequency and distribution of lightning as observed from space by the Optical Transient Detector. J. Geophys. Res., 108, 4005, doi:10.1029/2002JD002347.

Cummins, K. L., and M. J. Murphy, 2009: An overview of lightning locating systems: History, techniques, and data uses, with an in-depth look at the U.S. NLDN. IEEE Trans. Electromagn. Compat., 51, 499-518.

,-- E. A. Bardo, W. L. Hiscox, R. B. Pyle, and A. E. Pifer, 1998: A combined TOA/MDF technology upgrade of the U.S. National Lightning Detection Network. J. Geophys. Res., 103, 9035-9044.

Doswell, C. A., III, H. E. Brooks, and N. Dotzek, 2009: On the implementation of the enhanced Fujita scale in the USA. Atmos. Res., 93, 554-563.

Enno, S.-E., 2010: A climatology of cloud-to-ground lightning over Estonia, 2005-2009. Atmos. Res., in press, doi:10.1016/j.atmosres. 2010.08.024.

Fleagle, R. G., 1949: The audibility of thunder. J. Acoust. Soc. Amer., 21, 411-412.

Fritsch, J. M., and G. S. Forbes, 2001: Severe Convective Storms. Meteor. Monogr., No. 50, Amer. Meteor. Soc., 323-357.

Galway, J. G., 1989: The evolution of severe thunderstorm criteria within the Weather Service. Wea. Forecasting, 4, 585-592.

Hodanish, S., D. Sharp, W. Collins, C. Paxton, and R. E. Orville, 1997: A 10-yr monthly lightning climatology of Florida: 198695. Wea. Forecasting, 12, 439-448.

Houze, R. A., Jr., 2004: Mesoscale convective systems. Rev. Geophys., 42, RG4003, doi:10.1029/2004RG000150.

Huffines, G. R., and R. E. Orville, 1999: Lightning ground flash density and thunderstorm duration in the continental United States: 1989-96. J. Appl. Meteor., 38, 1013-1019.

Kar, S. K., Y. A. Liou, and K. J. Ha, 2007: Characteristics of cloudto-ground lightning activity over Seoul, South Korea, in relation to an urban effect. Ann. Geophys., 25, 2113-2118.

_ , Y.-A. Liou, and K.-J. Ha, 2009: Aerosol effects on the enhancement of cloud-to-ground lightning over major urban areas of South Korea. Atmos. Res., 92, 80-87.

Kuleshov, Y., and E. R. Jayaratne, 2004: Estimates of lightning ground flash density in Australia and its relationship to thunderdays. Aust. Meteor. Mag., 53, 189-196.

Lang, T. J., and S. A. Rutledge, 2002: Relationships between convective storm kinematics, precipitation, and lightning. Mon. Wea. Rev., 130, 2492-2506.

MacGorman, D. R., M. W. Maier, and W. D. Rust, 1984: Lightning strike density for the contiguous United States from thunderstorm duration records. Office of Nuclear Regulatory
Research, U.S. Nuclear Regulatory Commission, Rep. NUREG/CR-3759, 44 pp.

Mäkelä, A., and T. J. Tuomi, 2009: Lightning observations in Finland, 2009. Reports of Finnish Meteorological Institute, Rep. 2009:5, 64 pp. [Available from http://helda.helsinki.fi/ bitstream/handle/10138/14831/2009nro5.pdf.]

- - — - and J. Haapalainen, 2010: A decade of high-latitude lightning location: Effects of the evolving location network in Finland. J. Geophys. Res., 115, D21124, doi:10.1029/ 2009JD012183.

Naccarato, K. P., O. Pinto Jr., and I. R. C. A. Pinto, 2003: Evidence of thermal and aerosol effects on the cloud-to-ground lightning density and polarity over large urban areas of southeastern Brazil. Geophys. Res. Lett., 30, 1674, doi:10.1029/ 2003GL017496.

Orville, R. E., 1991: Lightning ground flash density in the contiguous United States-1989. Mon. Wea. Rev., 119, 573-577. 1994: Cloud-to-ground lightning flash characteristics in the contiguous United States: 1989-1991. J. Geophys. Res., 99, $10833-10841$.

_ 2008: Development of the National Lightning Detection Network. Bull. Amer. Meteor. Soc., 89, 180-190.

_ contiguous United States: 1992-95. Mon. Wea. Rev., 125, 631-638. , and G. R. Huffines, 1999: Lightning ground flash measurements over the contiguous United States: 1995-97. Mon. Wea. Rev., 127, 2693-2703.

—, and —, 2001: Cloud-to-ground lightning in the United States: NLDN results in the first decade, 1989-98. Mon. Wea. Rev., 129, 1179-1193.

— R. W. Henderson, and L. F. Bosart, 1983: An East Coast lightning detection network. Bull. Amer. Meteor. Soc., 64, 1029-1030.

— , G. R. Huffines, W. R. Burrows, R. L. Holle, and K. L. Cummins, 2002: The North American Lightning Detection Network (NALDN)_First results: 1998-2000. Mon. Wea. Rev., 130, 20982109.

Peckham, D. W., M. A. Uman, and C. E. Wilcox Jr., 1984: Lightning phenomenology in the Tampa Bay area. J. Geophys. Res., 89, 789-805.

Pinto, O., Jr., I. R. C. A. Pinto, M. A. S. S. Gomes, I. Vitorello, A. L. Padilha, J. H. Diniz, A. M. Carvalho, and A. C. Filho, 1999: Cloud-to-ground lightning in southeastern Brazil in 1993.1. Geographical distribution. J. Geophys. Res., 104, 31 369-31 379.

$\longrightarrow,-$ J. H. Diniz, A. C. Filho, L. C. L. Cherchiglia, and A. M. Carvalho, 2003: A seven-year study about the negative cloud-to-ground lightning flash characteristics in southeastern Brazil. J. Atmos. Sol.-Terr. Phys., 65, 739-748.

Prentice, S. A., 1972: CIGRE lightning flash counter. Electra, 22, 149-171.

Rakov, V. A., and M. A. Uman, 2003: Lightning Physics and Effects. Cambridge University Press, 850 pp.

Rodger, C. J., S. Werner, J. B. Brundell, E. H. Lay, N. R. Thomson, R. H. Holzworth, and R. L. Dowden, 2006: Detection efficiency of the VLF World-Wide Lightning Location Network (WWLLN): Initial case study. Ann. Geophys., 24, 3197-3214.

Rudlosky, S. D., and H. E. Fuelberg, 2010: Pre- and postupgrade distributions of NLDN reported cloud-to-ground lightning characteristics in the contiguous United States. Mon. Wea. Rev., 138, 3623-3633.

Samet, J., F. Dominici, F. Curriero, I. Coursac, and S. Zeger, 2000: Fine particulate air pollution and mortality in 20 U.S. cities, 1987-1994. N. Engl. J. Med., 343, 1743-1749. 
Schulz, W., K. Cummins, G. Diendorfer, and M. Dorninger, 2005: Cloud-to-ground lightning in Austria: A 10-year study using data from a lightning location system. J. Geophys. Res., 110, D09101, doi:10.1029/2004JD005332.

Seity, Y., S. Soula, and H. Sauvageot, 2001: Lightning and precipitation relationship in coastal thunderstorms. J. Geophys. Res., 106, 22 801-22 816.

Soriano, L. R., and F. de Pablo, 2002: Effect of small urban areas in central Spain on the enhancement of cloud-to-ground lightning activity. Atmos. Environ., 36, 2809-2816.

$\ldots,-$, and C. Tomas, 2005: Ten-year study of cloud-to-ground lightning activity in the Iberian Peninsula. J. Atmos. Sol.-Terr. Phys., 67, 1632-1639.

Speheger, D. A., C. A. Doswell III, and G. J. Stumpf, 2002: The tornadoes of 3 May 1999: Event verification in central Oklahoma and related issues. Wea. Forecasting, 17, 362-381.

Stallins, J. A., M. L. Bentley, and L. S. Rose, 2006: Cloud-to-ground flash patterns for Atlanta, Georgia (USA) from 1992 to 2003. Climate Res., 30, 99-112.

Steiger, S. M., and R. E. Orville, 2003: Cloud-to-ground lightning enhancement over southern Louisiana. Geophys. Res. Lett., 30, 1975, doi:10.1029/2003GL017923.

, - _ , and G. Huffines, 2002: Cloud-to-ground lightning characteristics over Houston, Texas: 1989-2000. J. Geophys. Res., 107, 4117, doi:10.1029/2001JD001142.
Stuhlmann, R., A. Rodriguez, S. Tjemkes, J. Grandell, A. Arriaga, J. Bézy, D. Aminou, and P. Bensi, 2005: Plans for EUMETSAT's Third Generation Meteosat geostationary satellite programme. Adv. Space Res., 36, 975-981.

Trapp, R. J., D. M. Wheatley, N. T. Atkins, R. W. Przybylinski, and R. Wolf, 2006: Buyer beware: Some words of caution on the use of severe wind reports in postevent assessment and research. Wea. Forecasting, 21, 408-415.

Tuomi, T. J., and A. Mäkelä, 2008: Thunderstorm climate of Finland 1998-2007. Geophysica, 44, 1-8.

Tuovinen, J.-P., A.-J. Punkka, J. Rauhala, H. Hohti, and D. M. Schultz, 2009: Climatology of severe hail in Finland: 1930-2006. Mon. Wea. Rev., 137, 2238-2249.

Westcott, N. E., 1995: Summertime cloud-to-ground lightning activity around major Midwestern urban areas. J. Appl. Meteor., 34, 1633-1642.

Williams, E. R., 2001: The electrification of convective storms. Severe Convective Storms, Meteor. Monogr., No. 50, Amer. Meteor. Soc., 527-561.

Zajac, B. A., and S. A. Rutledge, 2001: Cloud-to-ground lightning activity in the contiguous United States from 1995 to 1999. Mon. Wea. Rev., 129, 999-1019.

Zipser, E. J., D. J. Cecil, C. Liu, S. W. Nesbitt, and D. P. Yorty, 2006: Where are the most intense thunderstorms on Earth? Bull. Amer. Meteor. Soc., 87, 1057-1071. 